Japs: Jurnal Administrasi Politik dan Sosial, Vol. 1 No 2, Agustus 2020

P ISSN: 2722-161X e ISSN: 2722-1601

https://japs.ejournal.unri.ac.id/index.php/JAPS

\title{
Pemberdayaan Perempuan Melalui Implementasi Strategi Program Peningkatan Kualitass Hidup Dan Perlindungan Perempuan Di Provinsi Riau
}

\author{
${ }^{1}$ Puja Afwanda Mayako; ${ }^{2}$ Zaili Rusli; ${ }^{3}$ Adianto \\ 1,2Program Studi Magister Ilmu Administrasi Fisip Universitas Riau, Kampus Bina Widya. Jl. H.R. \\ Soebrantas Km. 12,5 Panam, Pekanbaru \\ Email: ${ }^{1}$ Mayakopuja@gmail.com,${ }^{2}$ zaili.rusli@lecturer.unri.ac.id dan ${ }^{3}$ adianto@lecturer.unri.ac.id
}

\begin{abstract}
Abstrak
Program peningkatan kualitas hidup dan perlindungan perempuan di provinsi riau merupakan program yang berfungsi untuk memberdayakan perempuan korban kekerasan. Penelitian ini bertujuan untuk mengetahui implementasi strategi program peningkatan kualitas hidup dan perlindungan perempuan di Provinsi Riau serta mengetahui faktor yang menghambat implementasi strategi program peningkatan kualitas hidup dan perlindungan perempuan di Provinsi Riau. Jenis penelitian ini adalah penelitian kualitatif dengan pendekatan studi kasus yang bersifat deskriptif. Hasil penelitian menemukan bahwa implementasi strategi program peningkatan kualitas hidup dan perlindungan perempuan di Provinsi Riau adalah baik. Karena dari semua penilaian yang dilakukan terhadap program, anggaran dan prosedur, semuanya menunjukan hasil yang sudah berjalan baik. Implementasi strategi program yang dilakukan oleh Dinas Pemberdayaan Perempuan dan Perlindungan Anak Provinsi Riau melalui UPT P2TP2A yang ditinjau dari program telah berjalan lebih dari satu tahun dan manfaat program ini telah dirasakan oleh korban KDRT yang mendapat penanganan. Ditinjau dari anggaran menunjukan bahwa anggaran yang digunakan sudah teraudit dan dilakukan pencatatan dalam dokumen rencana kerja anggaran sehingga dapat dipertanggungjawabkan. Kemudian ditinjau dari prosedur menunjukan bahwa dalam pelaksanaannya program peningkatan kualitas hidup dan perlindungan perempuan dijalankan sesuai standar operasional prosedur yang ada.
\end{abstract}

Kata kunci: Implementasi, Strategi, dan Program Peningkatan Kualitas Hidup dan Perlindungan Perempuan

\begin{abstract}
The program to improve the quality of life and protection of women in Riau Province is a program that functions to empower women victims of domestic violence. This study aims to determine the strategy implementation of life quality improvement and protection of women program in Riau Province, as well as determining the inhibiting factors of the program. This study uses qualitative research with a descriptive case study approach. The research results found that the implementation of the strategy program improved quality of life and protection of women in Riau Province is good. Because of all the assessments done on the program, budgets and procedures, all of them show the results that are already good. Implementation of the strategy of the program conducted by the Women Empowerment Office and Child protection of Riau Province through UPT P2TP2A which is reviewed from the program has been running for more than a year and the benefits of this program has been perceived by victims of domestic violence that received treatment. A review from the budget indicates that the budget used has been audited and recorded in the document of the budget work plan so that it can be accounted for. Then reviewed from the procedure shows that in the implementation of quality of life improvement program and women protection is executed according to the operational standards of the existing procedures.
\end{abstract}

Keywords: Implementation, Strategy, Program Improve Quality of Life and Protection Women 
Japs: Jurnal Administrasi Politik dan Sosial, Vol. 1 No 2, Agustus 2020

P_ISSN: 2722-161X e_ISSN: 2722-1601

https://japs.ejournal.unri.ac.ìd/index.php/JAPS

\section{Pemberdayaan Perempuan Melalui Implementasi Strategi Program Peningkatan Kualitass Hidup Dan Perlindungan Perempuan Di Provinsi Riau}

\section{PENDAHULUAN}

Kaum perempuan adalah kaum yang sangat sering mendapat perlakuan tidak adil dan tidak wajar sehingga sebagian besar perempuan tidak merasakan kesejahteraan lahir dan batin. Kekerasan perempuan adalah semua yang menimpa kaum perempuan, seperti pemukulan, penyiksaan, perlakuan kasar, atau pemaksaan untuk melakukan suatu pekerjaan yang tidak dia sukai. Kekerasan tersebut mencakup penyiksaan terhadap fisik, mental, pemerkosaaan, penghinaan, pelecehan seksual, ancaman dan pemaksaan untuk menjadi pelacur baik yang dilakukan oleh perorangan maupun organisasi. Salah satu cara yang rasional untuk membebaskan para perempuan dari masalah yang ada dengan memberdayakan perempuan untuk membebaskan perempuan dari sejumlah faktor yang menghambat mereka dalam mengembangkan diri. Pemberdayaan perempuan adalah suatu proses yang memungkinkan setiap perempuan mampu mengembangkan potensi-potensi yang dimilikinya dan mampu menentukan pilihannya sendiri secara bijaksana. Sebab pemberdayaan perempuan harus berhasil memperbaiki fungsi dari kemampuan perempuan sebagai mitra sejajar bagi kaum laki-laki. Keberadaan perempuan yang jumlahnya lebih besar dari laki-laki membuat pendekatan pemberdayaan dianggap suatu strategi yang melihat perempuan bukan sebagai beban pembangunan melainkan potensi yang harus dimanfaatkan untuk menunjang proses pembangunan.

Pemerintah Provinsi Riau menunjukan satu keseriuasan dalam upaya mengatasi kasus kekerasan pada perempuan dengan konsep pemberdayaan dengan mengeluarkan Peraturan Daerah Provinsi Riau Nomor 6 Tahun 2017 tentang Perlindungan Hak Perempuan Dari Tindak Kekerasan. Kebijakan ini bertujuan untuk: a). Mencegah tindak kekerasan terhadap perempuan termasuk perdagangan orang. b). Menghapus segala bentuk kekerasan dan eksploitasi terhadap perempuan. c) Melindungi, memberikan rasa aman bagi perempuan. d). Memberikan pelayanan kepada perempuan korban tindak kekerasan, pelapor, dan saksi. e). Memfasilitasi dan melakukan mediasi terhadap sengketa rumah tangga untuk mewujudkan keutuhan rumah tangga yang harmonis dan sejahtera. f). melakukan pemberdayaan kepada perempuan korbankekerasan. Selanjutnya kebijakan ini juga memiliki asas penghormatan dan pemenuhan terhadap hakhakkorban, keadilan dan kesetaraan gender, non diskriminasi, kepentingan terbaik bagi korban, dan pemberdayaan. Pemberdayaan merupakan salah satu azas yang diutamakan dalam upaya memberikan perlindungan hak perempuan dari tindakan kekerasan. Pemberdayaan perempuan tidak hanya berbentuk pemberdayaan pengembangan di bidang ekonomi saja. Namun pemberdayaan perempuan dapat berbentuk pemihakan, penyiapan serta perlindungan kepada perempuan hingga perempuan yang mendapat tindakan kekerasan kembali mendapat kepercayaan dirinya dalam melanjutkan hidup.

Kasus kekerasan terhadap perempuan di Provinsi Riau menunjykkan angka yang fluktuatif, hal ini dapat ditunjukan dari data yang diperoleh sebagai berikut. 
Grafik 1.

Kasus Kekerasan terhadap Perempuan di Provinsi Riau

(Periode 2014 - 2019)

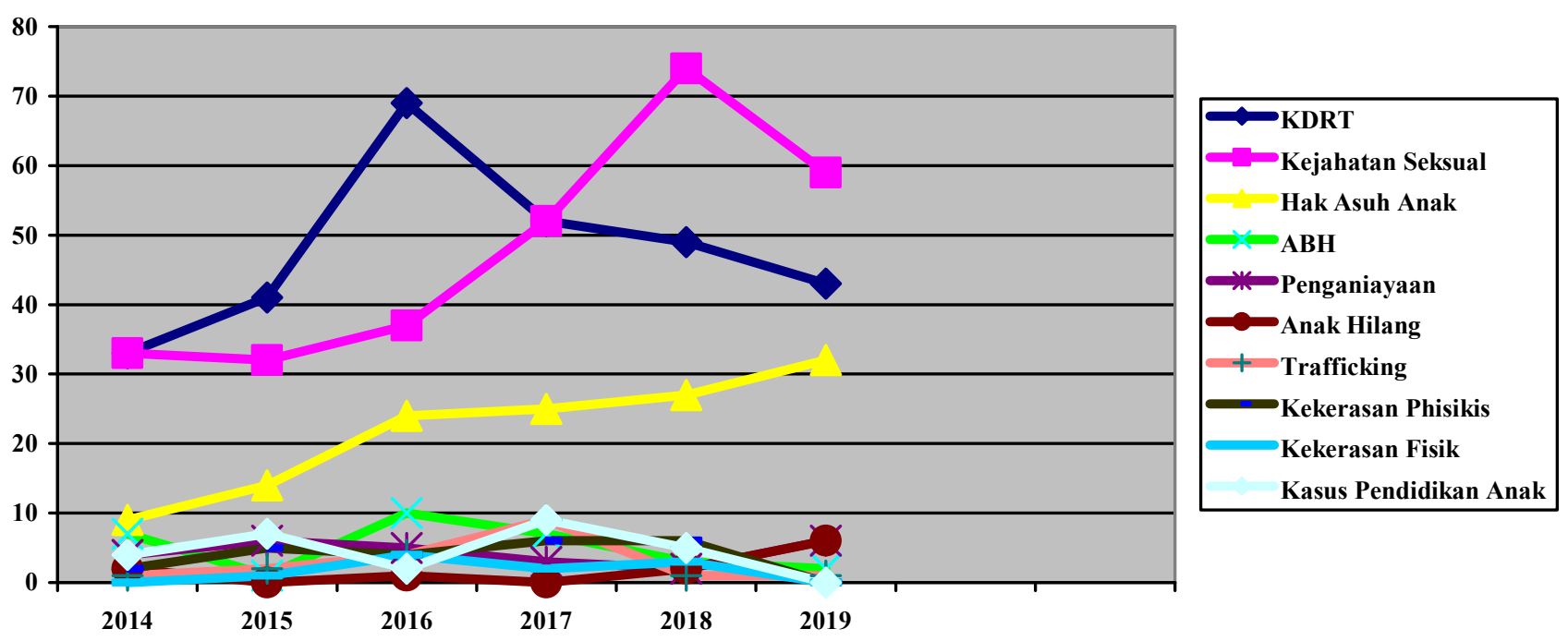

Sumber: UPT.P2TP2A Provinsi Riau, Tahun 2020

Data ini menunjukkan bahwa kasus kekerasan terhadap perempuan di Provinsi Riau masih tinggi. Kasus yang peling sering muncul tentang kekerasan terhadap perempuan yaitu KDRT dan kejahatan seksual. Kasus KDRT umumnya terjadi disebabkan oleh pembelaan atas kekuasaan laki-laki dianggap sebagai superioritas sumber daya dibandingkan dengan wanita. Sehingga mampu mengatur dan mengendalikan wanita, diskriminasi dan pembatasan kesempatan bagi wanita untuk bekerja mengakibatkan wanita (istri) ketergantungan terhadap suami dan ketika suami kehilangan pekerjaan maka istri mengalami tindakan kekerasan. Berdasarkan Undang-Undang Nomor 23 tahun 2004 tentang PKDRT pada pasal 1 butir 1 menyebutkan bahwa kekerasan dalam rumah tangga adalah setiap perbuatan terhadap seseorang terutama perempuan, yang berakibat timbulnya kesengsaraan atau penderitaan secara fisik, seksual, psikologis dan atau penelantaran rumah tangga termasuk ancaman untuk melakukan perbuatan, pemaksaan atau perempasan kemerdekaan secara melawan hukum dalam lingkup rumah tangga.

Implementasi Peraturan Daerah Provinsi Riau Nomor 6 Tahun 2017 tentang Perlindungan Hak Perempuan Dari Tindak Kekerasan dilaksanakan oleh Dinas Pemberdayaan Perempuan dan Perlindungan Anak. Bentuk program yang dilakukan dalam peraturan daerah ini salah satunya adalah program peningkatan kualitas hidup dan perlindungan perempuan. Program ini merupakan wujud nyata dalam upaya memberdayakan perempuan korban tindak kekerasan. Kegiatan yang diimplementasikan melalui program ini salah satunya adalah peningkatan perlindungan perempuan dan anak terhadap tindak kekerasan. Kegiatan ini berisi aktivitas konseling, pendampingan, penanganan serta rujukan bagi korban kekerasan perempuan dan anak se-Provinsi Riau melalui UPT Pusat Pelayanan Terpadu Perlindungan Perempuan dan Anak Provinsi Riau. Perempuan sebagai korban kekerasan, memang sudah seharusnya mendapatkan 
tindakan pemberdayaan agar tetap bisa melanjutkan hidup terlepas dari apa yang telah mereka alami. Pemberdayaan tersebut merupakan proses untuk memperoleh daya, kekuatan atau kemampuan dan atau pemberian daya, kekuatan atau kemampuan dari pihak yang memiliki daya kepada pihak yang kurang atau belum berdaya. Program peningkatan kualitas hidup dan perlindungan perempuan hadir sebagai salah satu program yang berperan dalam pemberdayaan perempuan korban kekerasan, maka perlu dilakukan implementasi strategi program peningkatan kualitas hidup dan perlindungan perempuan guna memastikan program ini berjalan sebagaimana mestinya dan manfaat pemberdayaan dapat dirasakan oleh para wanita yang menjadi korban tindak kekerasan.

Undang-undang Republik Indonesia Nomor 23 Tahun 2004 menjelaskan bahwa kekerasan dalam rumah tangga adalah setiap perbuatan terhadap seseorang terutama perempuan, yang berakibat timbulnya kesengsaraan atau penderitaan secara fisik, seksual, psikologis, dan/atau penelantaran rumah tangga termasuk ancaman untuk melakukan perbuatan, pemaksaan, atau perampasan kemerdekaan secara melawan hukum dalam lingkup rumah tangga. Soeroso (2011) berpendapat gender based violence atau kekerasan berbasis gender adalah istilah yang merujuk kepada kekerasan yang melibatkan laki-laki dan perempuan, biasanya yang menjadi korban adalah perempuan, sebagai akibat adanya distribusi kekuasaan yang timpang antara laki-laki dan perempuan. Sehingga dari makna tersebut bisa disimpulkan bahwa kekerasan terhadap perempuan adalah setiap perbuatan yang dikenakan pada seorang perempuan yang berakibat atau dapat menyebabkan kesengsaraan atau penderitaan secara fisik, psikologis atau seksual, termasuk juga ancaman perbuatan tertentu, pemaksaan atau perampasan kemerdekaan secara sewenang-wenang baik yang terjadi di muka umum maupun dalam kehidupan pribadi.

Suharto (2014) menjelaskan bahwa pemberdayaan merupakan serangkaian kegiatan untuk memperkuat kekuasaan atau keberdayaan kelompok lemah dalam masyarakat,termasuk individu-individu yang mengalami masalah kemiskinan/kekerasan, sebagai tujuan yang menunjuk pada keadaan atau hasil yang ingin dicapai oleh sebuah perubahan sosial yaitu masyarakat yang berdaya, memiliki kekuasaan atau mempunyai pengetahuan dan kemampuan dalam memenuhi kebutuhan hidupnya baik yang bersifat fisik, ekonomi maupun sosial seperti kepercayaan diri,mampu menyampaikan aspirasi, mempunyai mata pencaharian,berpartisipasi dalam kegiatan sosial, dan mandiri dalam melaksanakan tugas-tugas kehidupannya. Prijono.S.Onny dan Pranarka (1996) mengemukakan pemberdayaan adalah proses kepada masyarakat agar menjadi berdaya, mendorong atau memotivasi individu agar mempunyai kemampuan atau keberdayaan untuk menentukan pilihan hidupnya dan pemberdayaan harus ditujukan pada kelompok atau lapisan masyarakat tertinggal, Oleh karenanya, pemberdayaan dapat disimpulkan sebagai proses mengembangkan potensi-potensi yang dimiliki oleh individu atau kelompok untuk berkembang dan berdaya dalam upaya mengatasi permasalahan hidup yang dialami.

Amirullah (2015) mengungkapkan implementasi strategi adalah sebuah tindakan pengelolaan bermacam-macam sumber daya organisasi dan manajemen yang mengarahkan dan mengendalikan pemanfaatan sumber-sumber daya organisasi melalui strategi yang dipilih. Implementasi strategi diperlukan untuk memerinci secara lebih tepat dan jelas bagaimana sesungguhnya pilihan strategi yang telah diambil direalisasikan. Implementasi strategi yang berhasil sangat tergantung pada keahlian dan kemampuan serta keterampilan manajer. Salusu (2006) menjelaskan implementasi strategi merupakan seperangkat kegiatan yang dilakukan berdasarkan suatu keputusan yang prosesnya terarah dan terkoordinasi serta melibatkan sumber 
daya. Sifat dari suatu implementasi adalah tidak dapat beroperasi tanpa adanya factor internal dan eksternal yang mempengaruhinya.

Hunger dan Wheelen (2003) menyatakan implementasi strategi adalah sejumlah total aktivitas dan pilihan yang dibutuhkan untuk dapat menjalankan sebuah perencanaan strategis. Implementasi strategi merupakan proses berbagai strategi dan kebijakan berubah menjadi tindakan melalui pengembangan program, anggaran dan prosedur. Implementasi merupakan kunci sukses manajemen strategis, adapun tahapan implementasi strategi adalah sebagai berikut.

1. Program

Program adalah pernyataan aktivitas-aktivitas atau langkah-langkah yang diperlukan untuk menyelesaikan perencanaan sekali pakai.

2. Anggaran

Anggaran adalah program yang dinyatakan dalam bentuk satuan uang, setiap program akan dinyatakan secara rinci dalam biaya, yang dapat digunakan oleh manajemen untuk merencanakan dan mengendalikan.

3. Prosedur

Prosedur adalah sistem langkah-langkah atau teknik-teknik yang berurutan yang menggambarkan secara rinci bagaimana suatu tugas atau pekerjaan diselesaikan.

\section{METODE PENELITIAN}

Jenis penelitian ini adalah penelitian kualitatif dengan pendekatan studi kasus yang bersifat deskriptif. Alasan peneliti menggunakan jenis penelitian kualitatif adalah untuk mengetahui cara pandang obyek penelitian lebih mendalam yang tidak bisa diwakili dengan angka-angka statistik. Melalui metode kualitatif peneliti dapat mengenal orang (informan penelitian) secara pribadi dan melihat mereka mengembangkan definisi mereka sendiri tentang topik penelitian yang sedang dibahas. Pendekatan studi kasus juga dipilih karena pendekatan ini merupakan salah satu gejala sosial yang sedang trend dimasa kini sehingga peneliti dapat mengakses peristiwa/gejala sosial yang diteliti melalui pengamatan dan wawancara mendalam dengan informan penelitian. Selanjutnya sifat deskriptif yang dipilih untuk menggambarkan secara sistematis sebuah fakta dan karakteristik topik penelitian secara tepat.

Informan penelitian yang dipilih meliputi Kepala UPT P2TP2A Provinsi Riau, Kepala Seksi Perlindungan Hak Perempuan dan Khusus Anak Provinsi Riau, Kepala Seksi Penanganan dan Pemulihan Pusat Pelayanan Terpadu Perlindungan Perempuan dan Anak Provinsi Riau, Kepala Sub Bagian Tata Usaha Provinsi Riau dan korban Kekerasan KDRT. Pengumpulan data penelitian menggunakan tehnik pengamatan/observasi, wawancara dan dokumentasi. Setelah data terkumpul kemudian dianalisis dengan menggunakan model Miles and Hubermen yang memiliki tahapan: a). Pengumpulan data (data collecting), b). Reduksi data (data reduction), c). Penyajian data (data display) dan d). Penarikan kesimpulan (verification).

\section{HASIL DAN PEMBAHASAN}

Implementasi strategi program peningkatan kualitas hidup dan perlindungan perempuan merupakan proses dimana beberapa strategi dan kebijakan diubah menjadi tindakan melalui pengembangan program, anggaran dan prosedur. Suatu program dibuat tentu dengan tujuan agar program tersebut dapat berjalan dan bermanfaat, untuk itu implementasi strategi program 
Japs: Jurnal Administrasi Politik dan Sosial, Vol. 1 No 2, Agustus 2020

P ISSN: 2722-161X e ISSN: 2722-1601

https://japs.ejournal.unri.ac.id/index.php/JAPS

diperlukan guna memastikan bahwa program peningkatan kualitas hidup dan perlindungan perempuan benar-benar berjalan sesuai dengan tujuan program, anggaran dan prosedur yang ada.

\section{A. Program}

Program merupakan salah satu hal yang penting di dalam sebuah organisasi karena dengan adanya program maka suatu organisasi dapat menemukan hasil atau perubahan yang ingin dicapai. Program merupakan segala sesuatu yang dilakukan oleh seseorang dengan harapan akan mendatangkan hasil atau pengaruh (Joan L. Herman dalam Farida, 2008). Program tentu tidak dapat dipastikan akan selalu berhasil, karena terkadang program dapat saja gagal karena disebabkan oleh berbagai faktor. Program peningkatan kualitas hidup dan perlindungan perempuan merupakan suatu hal yang penting dilakukan karena program ini merupakan salah satu bentuk nyata dari upaya pemberdayaan perempuan korban kekerasan khususnya korban kekerasan dalam rumah tangga. Guna memperoleh informasi dan data yang dibutuhkan, peneliti melakukan wawancara dengan informan Kepala UPT P2TP2A Provinsi Riau, Kepala Seksi Perlindungan Hak Perempuan dan Khusus Anak Provinsi Riau, Kepala Seksi Penanganan dan Pemulihan Pusat Pelayanan Terpadu Perlindungan Perempuan dan Anak Provinsi Riau, Kepala Sub Bagian Tata Usaha Provinsi Riau dan korban Kekerasan KDRT, sebagai berikut.

Program peningkatan kualitas hidup dan perlindungan perempuan ini sudah berjalan lebih dari 1 tahun, sehingga program ini sudah dapat dirasakan manfaat bagi para peserta yang mengikutinya. Berdasarkan wawancara yang telah peneliti lakukan diperoleh informasi bahwa dalam pelaksanaannya, program ini dijalankan oleh dua unit kerjayang saling berkaitan yaitu Bidang Perlindungan Hak Perempuan dan Khusus Anak Provinsi Riau berkolaborasi atau bekerjasama dengan pihak UPT P2TP2A Provinsi Riau. Bidang Perlindungan Hak Perempuan dan Khusus Anak Provinsi Riau bertugas sebagai pembinaan,pelatihan,workshop, sedangkan untuk penanganan kasus merupakan tugas dari UPT P2TP2A. UPT P2TP2A pada dasarnya unit kerja yang mendukung dan membantu tugas Bidang Perlindungan Hak Perempuan dan Khusus Anak Provinsi Riau dalam menghadapi kasus kekerasan dalam rumah tangga. Dimana Bidang Perlindungan Hak Perempuan dan Khusus Anak Provinsi Riau fokus dalam hal memberikan penyuluhan, pembinaan, pelatihan-pelatihan seputar kekerasan dalam rumah tangga yang bertujuan agar menambah pengetahuan bagi para perempuan atau peserta pelatihan tentang bagaimana seharusnya bertindak bila mendapatkan perlakuan kekerasan dalam rumah tangga, serta pengetahuan-pengetahuan lainnya yang dapat memperkecil terjadinya kasus kekerasan dalam rumah tangga.

Pemberdayaan perempuan korban kekerasan yang diberikan melalui kegiatan pelatihan dan penyuluhan tentang tindakan preventif (pencegahan) kekerasan dalam rumah tangga. Walaupun dalam realitasnya tindakan kekerasan dalam rumah tangga masih saja terjadi, maka selanjutnya tugas UPT P2TP2A membantu dalam hal pelayanan penanganan serta bantuan bagi para korban KDRT hingga masalah yang mereka hadapi dapat terselesaikan. Suatu program tentu akan berhasil bila didalamnya terdapat kegiatan-kegiatan yang mendukung berjalannya suatu program. Sama halnya dengan program peningkatan kualitas hidup dan perlindungan perempuan ini yang juga di dukung oleh berbagai kegiatan-kegiatan dalam pelaksanaanya, baik itu kegiatan yang dilakukan oleh Bidang Perlindungan Hak Perempuan dan Khusus Anak Provinsi Riau maupun kegiatan yang dilakukan oleh pihak UPT P2TP2A.

Bidang Perlindungan Hak Perempuan dan Khusus Anak Provinsi Riau dan UPT P2TP2A telah berupaya dalam mensukseskan program peningkatan kualitas hidup dan perlindungan 
perempuan, ini dibuktikan dengan dilaksanakannya kegiatan-kegiatan dari kedua belah pihak. Kegiatan sosialisasi yang dilakukan dapat memberikan pengetahuan bagi para perempuan yang belum mendapat tindakan kekerasan dalam rumah tangga agar lebih bijak dan lebih siap jika sewaktu-waktu hal yang tidak diinginkan seperti tindakan kekerasan, pelecehan seksual maupun penelantaran dalam rumah tangga menimpa dirinya. Sosialisasi ini juga dapat memberikan pengetahuan bagi para perempuan baik yang sudah memiliki keluarga maupun para perempuan yang belum berkeluarga (belum menikah) agar jika nanti sudah berada dalam ikatan pernikahan bisa lebih bijak untuk meminimalisir konflik dari pelajaran dan informasi yang didapatkan selama mengikuti sosialisasi.

Kegiatan-kegiatan yang dilakukan oleh pihak UPT P2TP2A juga dirasa dapat meringankan beban para perempuan dan anak yang mendapat kekerasan dalam rumah tangga. Program peningkatan kualitas hidup dan perlindungan perempuan yang dilaksanakan dalam bentuk-bentuk kegiatan sebagai berikut.

1. Pendampingan Korban

Kegiatan pendampingan korban ini dapat menambah kepercayaan diri bagi korban untuk menghadapi rangkaian proses dalam penyelesaian kasus KDRT yang ia hadapi. Pendampingan yang dilakukan membuat korban tahu langkah apa yang harusnya ia tempuh. Seperti kita tahu, tidak semua orang dapat beruntung mengenyam pendidikan hingga ke jenjang yang lebih tinggi serta tidak semua orang berpengalaman dalam menghadapi suatu kasus KDRT. Kegiatan pendampingan korban ini akan menambah rasa percaya diri dan membuat korban yang tadinya merasa tidak berdaya menjadi lebih tenang karena ia tahu ada pihak-pihak yang bersedia mendampinginya hingga permasalahan yang ia hadapi dapat terselesaikan. Pendampingan korban juga dirasa memang perlu dan dibutuhkan mengingat dalam kasus KDRT tidaklah sama penanganan dan tingkat permasalahan yang terjadi. Bila korban mendapat tindakan KDRT dari segi kekerasan terhadap fisik, maka korban tersebut memerlukan pendampingan ke rumah sakit bahkan ke lembaga kepolisian guna menyelidiki dan mengusut kasus yang korban tersebut hadapi. Namun bila tindakan KDRT yang ia dapatkan lebih melukai sisi psikologis korban, tentu pendampingan yang ia terima akan berbeda.

2. Penjangkauan Korban

Penjangkauan korban merupakan kegiatan atau aktivitas yang dilakukan oleh UPT P2TP2A guna melihat dan mengunjungi korban yang mendapat tindak kekerasan dalam rumah tangga. Biasanya kegiatan ini dilakukan untuk melihat dan mendapatkan informasi lebih lanjut tentang permasalahan serta KDRT yang telah korban terima khususnya bagi para korban yang tidak dapat mendatangi kantor UPT P2TP2A. Penjangkauan korban ini terkadang juga dilakukan guna meninjau kembali bagaimana perkembangan kondisi korban setelah melewati rangkaian proses penyelesaian kasusnya. Bila korban baru saja menjalani terapi psikologis maka akan dilakukan penjangkauan korban guna mengamati sejauh mana perekembangan kesembuhan psikologis korban.

3. Penanganan Korban

Kegiatan ini merupakan rangkaian dari berbagai aktivitas dalam menghadapi permasalahan korban. Maksudnya setiap korban yang datang pada pihak UPT P2TP2A memiliki permasalahan yang tidak sama, setiap kasus memerlukan penanganan yang berbeda-beda. Jika korban datang dengan luka fisik akibat kekerasan dalam rumah tangga maka penanganan 
yang tepat setelah menerima berkas pengaduan adalah dengan merujuk korban ke rumah sakit atau pusat layanan kesehatan guna mengobati luka fisik yang korban terima. Namun jika korban datang dan membuat berkas pengaduan bahwa korban membutuhkan bantuan hukum, tentu penanganan yang dilakukan adalah dengan mendampingi korban agar mendapat bantuan hukum guna menghadapi permasalahan yang ia terima.

4. Mediasi

Kegiatan ini adalah kegiatan yang dilakukan pihak UPT P2TP2A guna menengahi kasus kekerasan dalam rumah tangga yang terjadi dalam suatu keluarga. Biasanya kedua pihak yang bersengketa akan dipanggil dan dipertemukan untuk selanjutnya akan bersama-sama membicarakan bagaimana jalan keluar yang diinginkan oleh kedua belah pihak tanpa merugikan salah satu pihak yang bersengketa. Kebanyakan kegiatan mediasi ini dilakukan oleh korban yang mendapat tindakan penelantaran dari salah satu pasangan mereka. Sehingga dengan adanya mediasi diharapkan penelantaran yang menimpa korban segera teratasi dan korban dapat mendapatkan hak-hak yang seharusnya ia terima kembali.

Berdasarkan hasil dan pembahasan yang dilakukan tentang program maka dapat disimpulkan telah berjalan dengan baik. Hal ini terlihat dari terlaksananya kolaborasi yang dilakukan antara Bidang Perlindungan Hak Perempuan dan Khusus Anak Provinsi Riau dan UPT P2TP2A dirasa sudah saling melengkapi. Sebab program ini yang diimplementasikan sudah memiliki kegiatan pencegahan dan kegiatan penanganan. Sebelum tindakan KDRT terjadi upaya yang sangat tepat untuk mencegahnya adalah dengan melaksanakan kegiatan sosialisasi seputar KDRT agar orang-orang yang ikut serta dalam sosialisasi tersebut mendapat banyak informasi yang dapat ia gunakan untuk mencegah dirinya terhindar menjadi korban kekerasan dalam rumah tangga. Apabila kegiatan pencegahan sudah dilaksanakan dan kasus KDRT masih tetap terjadi, maka kegiatan penanganan adalah kegiatan dan langkah yang sangat tepat untuk membantu para perempuan yang merasa tidak berdaya untuk dapat merasa percaya diri kembali. Meskipun program ini tidak memberdayakan dari sisi pengembangan ekonomi perempuan korban KDRT, namun dengan memberikan sosialisasi dan penanganan serta perlindungan terhadap korban KDRT merupakan suatu langkah yang baik untuk memberikan daya pada mereka yang menghadapi permasalahan KDRT tersebut. Seorang korban yang sedang menghapi suatu masalah biasanya akan cenderung merasa lemah dan tidak berdaya. Sebagian besar dari mereka bahkan tidak tahu ingin menceritakan dan meminta bantuan kepada siapa terkait permasalahannya.

\section{B. Anggaran}

Anggaran merupakan pernyataan mengenai sistemasi kinerja yang hendak dicapai selama periode tertentu yang dinyatakan dalam ukuran finansial. Pada organisasi sektor publik anggaran merupakan instrument akuntabilitas dan pengelolaaan dana publik serta pelaksanaan programprogram yang dibiayai dengan uang publik. Program peningkatan kualitas hidup dan perlindungan perempuan merupakan program yang bertujuan untuk membantu menyelesaikan salah satu permasalahan publik yakni masalah kekerasan dalam rumah tangga yang menimpa kaum perempuan oleh karenanya program ini membutuhkan anggaran yang bisa digunakan untuk mengimplementasikan program tersebut. Guna memperoleh informasi dan data yang dibutuhkan, peneliti melakukan wawancara dengan informan Kepala UPT P2TP2A Provinsi Riau, Kepala Seksi Perlindungan Hak Perempuan dan Khusus Anak Provinsi Riau, Kepala Seksi 
Japs: Jurnal Administrasi Politik dan Sosial, Vol. 1 No 2, Agustus 2020

P ISSN: 2722-161X e ISSN: 2722-1601

https://japs.ejournal.unri.ac.id/index.php/JAPS

Penanganan dan Pemulihan Pusat Pelayanan Terpadu Perlindungan Perempuan dan Anak Provinsi Riau, Kepala Sub Bagian Tata Usaha Provinsi Riau dan korban Kekerasan KDRT, sebagai berikut.

Program peningkatan kualitas hidup dan perlindungan perempuan dijalankan menggunakan anggaran yang bersumber dari APBD Provinsi Riau. Untuk memastikan bahwa anggaran yang digunakan oleh Bidang Perlindungan Hak Perempuan dan Khusus Anak Provinsi Riau dan UPT P2TP2A sebagai implementor dalam pelaksanaan program ini, maka audit dilakukan oleh pihak luar yang tidak berada dalam organisasi yang menjalankan program yakni badan inspektorat yang akan memeriksa apakah anggaran yang dikeluarkan sesuai dengan rencana kerja organisasi tersebut. Pemeriksaan atau audit yang dilakukan oleh pihak inspektorat membuat pengauditan berjalan secara objektif karena tidak akan ada keberpihakan terhadap penyalahgunaan anggaran yang dapat saja sewaktu-waktu terjadi dalam pelaksanaan suatu program.

Bidang Perlindungan Hak Perempuan dan Khusus Anak Provinsi Riau dan UPT P2TP2A menggunakan anggaran dengan cukup baik dan telah melakukan pencatatan terhadap penggunaan anggaran dalam dokumen rencana kerja anggaran. Anggaran semuanya digunakan untuk keperluan kegiatan demi mensukseskan terlaksananya program ini. Hal ini dibuktikan dengan semua biaya yang dikeluarkan dalam menangani kasus kekerasan dalam rumah tangga yang dilaporkan oleh para korban kepada pihak UPT P2TP2A semuanya ditanggung oleh Dinas Pemberdayaan Perempuan dan Perlindungan Anak melalui UPT P2TP2A. Sehingga para korban tidak perlu mengeluarkan uang untuk proses penyelesaian kasusnya. Misalnya apabila korban memerlukan psikolog, maka biaya yang dikeluarkan untuk membayar psikolog semuanya ditanggung oleh pihak UPT P2TP2A, begitu juga bila korban membutuhkan pengacara untuk membantunya dalam persidangan.

Selanjutnya pencatatan terhadap anggaran yang digunakan adalah salah satu cara untuk menghindari kecurangan-kecurangan terhadap dana anggaran yang dipergunakan. Pencatatan dapat menjadi tolak ukur seberapa banyak anggaran telah digunakan dan berapa banyak hasil yang terlihat dari penggunaan anggaran tersebut. Pencatatan terhadap dana anggaran yang dikeluarkan juga lebih memudahkan dalam hal akuntabiltas/pertanggungjawaban. Bila ditemukan ketidaksesuaian maka dapat dilakukan pencarian terhadap kecurangan atau kesalahan yang terjadi. Pencatatan terhadap anggaran yang dikeluarkan juga berfungsi untuk menciptakan sifat transparansi kepada publik, karena publik berhak tahu untuk apa dan kemana anggaran itu dipergunakan.

Berdasarkan hasil dan pembahasan yang dilakukan tentang anggaran maka dapat disimpulkan telah berjalan dengan baik. Hal ini dikerenakan anggaran dalam pemanfaatannya sudah dilakukan pencatatan dan pengauditan oleh badan inspektorat sehingga anggaran yang bersumber dari APBD dan merupakan uang yang bersumber dari publik ini dapat digunakan secara optimal serta bersifat transparan dan dapat dipertanggungjawabkan oleh pihak-pihak yang menggunakan anggaran dalam menjalankan program peningkatan kualitas dan perlindungan perempuan tersebut.

\section{Prosedur}

Prosedur merupakan serangkaian tahapan yang menjadi pedoman bagi suatu organisasi untuk membantu menjalankan suatu aktivitas demi mencapai sasaran yang telah ditargetkan. Prosedur adalah rangkaian tindakan, langkah, atau perbuatan yang harus dilakukan oleh seseorang, dan merupakan cara yang tetap untuk dapat mencapai tahap tertentu dalam hubungan mencapai tujuan akhir. Setiap tindakan atau kegiatan yang dilakukan dalam upaya pelaksanaan 
program peningkatan kualitas hidup dan perlindungan perempuan semuanya memiliki prosedur dan tahapan-tahapan hingga diputuskan langkah penanganan apa yang sekiranya dibutuhkan untuk menyelesaikan suatu kasus kekerasan dalam rumah tangga yang dihadapi oleh korban. Guna memperoleh informasi dan data yang dibutuhkan, peneliti melakukan wawancara dengan informan Kepala UPT P2TP2A Provinsi Riau, Kepala Seksi Perlindungan Hak Perempuan dan Khusus Anak Provinsi Riau, Kepala Seksi Penanganan dan Pemulihan Pusat Pelayanan Terpadu Perlindungan Perempuan dan Anak Provinsi Riau, Kepala Sub Bagian Tata Usaha Provinsi Riau dan korban Kekerasan KDRT, sebagai berikut.

Setiap tindakan atau kegiatan yang dilakukan dalam upaya pelaksanaan program peningkatan kualitas hidup dan perlindungan perempuan semuanya memiliki prosedur dan tahapan-tahapan hingga diputuskan langkah penanganan apa yang sekiranya dibutuhkan untuk menyelesaikan suatu kasus kekerasan dalam rumah tangga yang dihadapi oleh korban. Dinas Pemberdayaan Perempuan dan Perlindungan Anak Provinsi Riau melalui UPT P2TP2A sudah melaksanakan program ini dengan berlandaskan atas prosedur yang tersedia, dimana sejak diterimanya laporan dari korban hingga dilaksanakan penanganan telah tercantum di dalam standar operasional prosedur. SOP sudah dilaksanakan dari mulai level bawah hingga atas dalam impelementasi program peningkatan kualitas hidup dan perlindungan perempuan. Misalnya pada level bahwa seperti petugas layanan atau resepsionis yang melayani dan menanyakan maksud dan keperluan setiap orang yang datang untuk selanjutnya diberikan pelayanan sesuai dengan apa yang dibutuhkan. Jika yang datang adalah korban dan ingin melakukan pengaduan serta konsultasi, maka resepsionis akan menghubungi bagian administrasi atau pihak yang berkaitan dengan pengaduan dan konsultasi untuk selanjutnya ditangani oleh petugas yang berwenang menangani dibidangnya masing-masing.

Prosedur yang diterapkan oleh UPT P2TP2A mudah untuk diikuti oleh seluruh korban maupun seluruh orang yang sekiranya memiliki keperluan dengan pihak UPT P2TP2A. Dalam hal ini korban tidak akan kesulitaan untuk mengetahui tata cara pelaporan atau pengaduan terkait permasalahan yang ia hadapi. Karena pada ruangan tunggu yang berada tepat setelah pintu masuk UPT P2TP2A Provinsi Riau telah ditampilkan petunjuk pelaporan berupa alur pelayanan yang dapat dilihat dan dibaca oleh siapa saja yang berkunjung ke UPT P2TP2A. Informasi yang mudah dipahami serta alur tahapan pelayanan yang tidak berbelit-belit akan membantu korban yang mungkin sudah lelah dengan permasalahan yang ia hadapi untuk merasa lebih ringan mengikuti proses demi proses serta tahapan-tahapan guna menyelesaikan kasus yang ia sedang jalani.

Berdasarkan hasil dan pembahasan yang dilakukan tentang prosedur maka dapat disimpulkan telah berjalan dengan baik. Hal ini dikarenakan bahwa setiap kegiatan yang dilakukan dalam menjalankan program peningkatan kualitas hidup dan perlindungan perempuan semuanya dilakukan berdasarkan standar operasional prosedur yang ada sehingga kegiatan apapun yang dilakukan menjadi terarah serta terukur dan dapat dipertanggungjawabkan.

Hasil dan pembahasan yang telah dilakukan mengenai implementasi strategi program kualitas hidup dan perlindungan perempuan di Provinsi Riau disimpulkan baik. Karena dari semua penilaian yang dilakukan terhadap program, anggaran dan prosedur, semuanya menunjukan hasil yang sudah berjalan baik. Dimana dari sisi program sudah dilaksanakan 
dengan optimal dan mendapat respon positif dari korban yang sudah merasakan manfaat dari pelaksanaan program peningkatan kualitas hidup dan perlindungan perempuan. Kemudian dari sisi anggaran yang dipergunakan dalam pelaksanaan program ini juga sudah dilaksanakan pengauditan oleh pihak yang berwenang serta telah dilaksanakan pencatatan terhadap anggaran yang digunakan dalam bentuk dokumen rencana kerja anggaran yang terlampir pada bagian akhir tesis ini. Selanjutnya dari sisi prosedur, implementasi strategi program sudah dijalankan berdasarkan standart operasional prosedur yang berlaku. Sehingga dalam pelaksanaannya program ini menjadi lebih terarah dan terstruktur.

\section{KESIMPULAN}

Implementasi strategi program peningkatan kualitas hidup dan perlindungan perempuan di Provinsi Riau adalah baik. Karena dari semua penilaian yang dilakukan terhadap program, anggaran dan prosedur, semuanya menunjukan hasil yang sudah berjalan baik. Implementasi strategi program yang dilakukan oleh Dinas Pemberdayaan Perempuan dan Perlindungan Anak Provinsi Riau melalui UPT P2TP2A yang ditinjau dari program telah berjalan lebih dari satu tahun dan manfaat program ini telah dirasakan oleh korban KDRT yang mendapat penanganan. Ditinjau dari anggaran menunjukan bahwa anggaran yang digunakan sudah teraudit dan dilakukan pencatatan dalam dokumen rencana kerja anggaran sehingga dapat dipertanggungjawabkan. Kemudian ditinjau dari Prosedur menunjukan bahwa dalam pelaksanaannya program peningkatan kualitas hidup dan perlindungan perempuan dijalankan sesuai standar operasional prosedur yang ada. Penelitian ini juga menemukan faktor-faktor yang menghambat implementasi strategi program peningkatan kualitas hidup dan perlindungan perempuan di Provinsi Riau adalah: 1) Tidak semua daerah kabupaten/kota memiliki UPT P2TP2A dan kelengkapan ahli (psikolog/pengacara) 2) Adanya perpindahan SOTK (struktur organisasi dan tata kerja) Pegawai dari jabatan satu ke jabatan lainnya pada Dinas Pemberdayaan Perempuan Dan Perlindungan Anak Provinsi Riau.

\section{DAFTAR PUSTAKA}

Amirullah. 2015. Manajemen Srategi (Teori-Konsep-Kinerja). Jakarta: Mitra Wacana Media Denzin dan Lincon. 2009. Hanbook Of Qualitative Research. Yogyakarta: Pustaka Pelajar Hunger, J. David dan Thomas L. Wheelen. 2003. Manajemen Strategi. Yogyakarta: Andi

J. Salusu. 2006. Pengambilan Keputusan Strategik Untuk Organisasi Publik dan Organisasi NonProfit. Jakarta: Grasindo

Miles, B. Mathew dan Michael Huberman. 1992. Analisis Data Kualitatif Buku Sumber Tentang Metode-metode Baru. Jakarta: UIP

Moerti Hadiati Soeroso. 2011. Kekerasan Dalam Rumah Tangga Dalam Prespektif YuridisViktimologis. Jakarta: Sinar Grafika. 
Japs: Jurnal Administrasi Politik dan Sosial, Vol. 1 No 2, Agustus 2020

P_ISSN: 2722-161X e_ISSN: 2722-1601

https://japs.ejournal.unri.ac.id/index.php/JAPS

Peraturan Daerah Provinsi Riau Nomor 6 Tahun 2017 tentang Perlindungan Hak Perempuan Dari Tindak Kekerasan

Prijono,O.S. dan Pranarka, A.M.W. 1996. Pemberdayaan: Konsep, Kebijakan dan Implementasi. Jakarta: CSIS

Ranny Rahmawati, Sukidin, dan Pudjo Suharso. 2018. Pemberdayaan Perempuan Korban Kekerasan Dalam Rumah Tangga ( KDRT) Oleh Dinas Pemberdayaan Perempuan, Perlindungan Anak dan Keluarga Berencana ( DP3AKB) Kabupaten Jember. Jurnal Pendidikan Ekonomi. Volume 12 Nomor 2. Halaman 162-167

Siti Maimanah,DR.Paranoan,Jamal Amin.2015.Implementasi Program Pemberdayaan Perempuan dalam Mewujudkan Kesetaraan Gender di Kabupaten Kutai Kartanegara.Volume 3 Nomor 1.Halaman 127-137

Suharto, Edi. 2014. Pembangunan Kebijakan dan Kesejahteraan Sosial. Bandung: Mizan

Tanu Tandon. 2016. Women Empowerment : Perspektives and Views. Jurnal The International Journal Of Indian Psychology. Volume 3 Nomor 8. Halaman 5-12

Undang-undang Nomor 23 Tahun 2004 Tentang Penghapusan Kekerasan Dalam Rumah Tangga Zahoor Ahmed Watoo, Sunia Ayub, Muhammad Salman Shabbir, Uzma Baloch, dan Humara Nasar. 2015. Strategies For Empowering Women and Gender Equality Through Micro Finance In Finance. Jurnal International Jurnal of Academic Research in Accounting Finance and Management Sciences. Volume 5 Nomor 1. Halaman 171-178 